\title{
Synthesis, Characterization and Anticancer Activity Studies of New Schiff Base Pt (II) Complex
}

\author{
Sama A. Al-Aghbari1 ${ }^{*}$, Omar M. Al-Shuja'a², Rowaida Al-Badani' ${ }^{1}$, Abd Al-Wali M. Japir ${ }^{3,4}$ \\ ${ }^{1}$ Chemistry Department, Faculty of Pharmacy, University of Science \& Technology, Sana'a, Yemen \\ ${ }^{2}$ Chemistry Department, Faculty of Applied Science, Thamar University, Thamar, Yemen \\ ${ }^{3}$ CAS Key Laboratory of Soft Matter Chemistry, Department of Polymer Science and Engineering, University of Science and \\ Technology of China, Hefei, China \\ ${ }^{4}$ Department of Chemistry, Faculty of Education, Thamar University, Dhamar, Yemen \\ Email: *s.alaghbari.ust.edu
}

How to cite this paper: Al-Aghbari, S.A., Al-Shuja'a, O.M., Al-Badani, R. and Japir, A.A.-W.M. (2019) Synthesis, Characterization and Anticancer Activity Studies of New Schiff Base Pt (II) Complex. Journal of Materials Science and Chemical Engineering, 7, 1-8.

https://doi.org/10.4236/msce.2019.78001

Received: July 2, 2019

Accepted: August 2, 2019

Published: August 5, 2019

Copyright (C 2019 by author(s) and Scientific Research Publishing Inc. This work is licensed under the Creative Commons Attribution International License (CC BY 4.0).

http://creativecommons.org/licenses/by/4.0/

\begin{abstract}
A New Schiff base ligand and its Pt (II) complex were synthesized. The ligand was prepared by condensation of 2-(4-isobutylphenyl)propanehydrazide with 2,3,4-trihydroxy benzaldehyde this novel ligand and its functional group was carefully designed and selected from well-known biological drugs. The structure of the ligand and its Pt-complex have been confirmed by spectroscopic data, i.e. elemental (CHN) analysis, FT-IR, electronic spectra, NMR spectra. The ligand and its Pt-complex were investigated for their in vitro anticancer potential using HeLa and PC3 cells. The Pt-complex showed a higher cytotoxic activity than the ligand towards Hela cells and PC3 cells.
\end{abstract}

\section{Keywords}

Schiff Base, Complexes, Platinum, Anticancer Activity

\section{Introduction}

Schiff bases play an important role in development of coordination chemistry. Many coordination compounds of biologically active ligands have synthesized and received much attention [1] [2] [3].

Chelation causes drastic change in the biological properties or the ligands and also the metal moieties [4]. Azomethines exhibit a wide range of pharmacological activities like antimicrobial [5], anti-parasitic [6], anti-inflammatory [7] and anticancer [8]. Schiff base and its metal complexes possess several interesting biological activities such as anti-microbial and antitumor [9]-[15]. 
In this work, Schiff base ligand was prepared and complexed with Potassium tetrarchloroplatinate $\left(\mathrm{K}_{2} \mathrm{PtCl}_{4}\right)$. Characterization, electronic properties and anticancer effect are reported.

\section{Experimental}

\subsection{Chemicals}

The drug, chemicals and solvents used in this study were of analytical grade and used as obtained from Aldrich without further purification: Ibuprofen drug, hydrazine hydrate, Potassium tetrachloroplatinate (II) $\left(\mathrm{K}_{2} \mathrm{PtCl}_{4}\right)$, Methanol $\left(\mathrm{CH}_{3} \mathrm{OH}\right)$, deionized water.

\subsection{Instrumental}

The melting points were measured on an electro thermal melting point apparatus and were not corrected. Fourier-transform infrared spectra were recorded using the $\mathrm{KBr}$ disc technique on a JASCO 410 FTIR spectrophotometer. Elemental (CHN) analysis was performed using an Exeter CE-440 elemental analyzer. UV-visible absorption spectra were measured in DMF $\left(\approx 10^{-5} \mathrm{~mole}^{-1}\right)$ using a Pye-Unicam 8800a uv-visible automatic scanning spectrophotometer. HNMR spectra of the ligand and its complex were recorded on a Varian Gemini-200 spectrometer (300 MHZ) using DMSO- $d_{6}$ as solvent and TMS as internal reference. ${ }^{13} \mathrm{C}$ NMR spectra of the ligand in DMSO was obtained using a Bruker $500 \mathrm{MHZ}$ instrument using TMS as internal reference. Anticancer activity was evaluated at the Regional Center for Mycology and Biotechnology, Al-Azhar University, Cairo, Egypt.

\subsection{Synthesis of Schiff Base}

\section{Synthesis of Schiff base L}

The Schiff base ligand was prepared by condensation of mixture $(0.001 \mathrm{~mol})$ of 2-(4-isobutylphenyl)propanehydrazide and the 2,3,4-trihydroxybenzaldehyde in $(30 \mathrm{ml})$ methanol. The mixture was refluxing for $24 \mathrm{~h}$, The precipitated was filtered, crystallized by methanol, then dried in air for $24 \mathrm{~h}$. Compound 2-(4-isobutylphenyl)propanehydrazide was prepared according the literature [16].

\section{Synthesis of Schiff base Platinum Complex (L-Pt)}

The Schiff base Platinum complex (L-Pt) was prepared by mixing $(0.001 \mathrm{~mol})$ of $\mathrm{K}_{2} \mathrm{PtCl}_{4}$ was dissolved in $10 \mathrm{ml}$ of methanol with some amount of deionized water and $(0.001 \mathrm{~mol})$ of Schiff base $\mathrm{L}$ in $20 \mathrm{ml}$ of methanol. The mixture was refluxing for $24 \mathrm{~h}$, The precipitated complex was filtered, washed twice with methanol, then dried in air for $24 \mathrm{~h}$.

\subsection{Cytotoxicity}

Cell line Propagation

The cells were grown on RPMI-1640 medium supplemented with $10 \%$ inacti- 
vated fetal calf serum and $50 \mu \mathrm{g} / \mathrm{ml}$ gentamycin. The cells were maintained at $37^{\circ} \mathrm{C}$ in a humidified atmosphere with $5 \% \mathrm{CO}_{2}$ and were subculture two to three times a week.

Cytotoxicity evaluation using viability assay

For antitumor assays, the growth cell lines were suspended in medium at concentration $5 \times 10^{4}$ cell/well in Corning ${ }^{\oplus}$ 96-well tissue culture plates, then incubated for twenty-four hour. The tested compounds were then additional into 96 -well plates (3 replicates) to attain 12 concentrations for further compound. 6 vehicle controls with media or $1 / 2 \%$ dimethyl sulfoxide were run for each 96 well plate as a control. After incubating for twenty-four hour, the numbers of viable cells were determined by the MTT check. Briefly, the media was far from the 96 well plate and replaced with $100 \mu \mathrm{l}$ of fresh culture RPMI 1640 medium without phenol red then ten $\mu$ of the twelve mM MTT, stock solution (five mg of MTT in one mL of PBS) to each well including the untreated controls. The 96 well plates were then incubated at $37^{\circ} \mathrm{C}$ and five $\% \mathrm{CO}_{2}$ for four hours. An $85 \mu \mathrm{l}$ aliquot of the media was removed from the wells, and $50 \mu \mathrm{l}$ of DMSO was added to each well and mixed thoroughly with the pipette and incubated at $37^{\circ} \mathrm{C}$ for 10 min. Then, the optical density was measured at $590 \mathrm{~nm}$ with the microplate reader (SunRise, TECAN, Inc, USA)to see the quantity of viable cells and the percentage of viability was calculated as $[(\mathrm{ODt} / \mathrm{ODc})] \times 100 \%$ where $\mathrm{ODt}$ is the mean optical density of wells treated with the tested sample and ODc is the mean optical density of untreated cells. The relation between living cells and drug concentration is plotted to get the survival curve of each tumor cell line after treatment with the required compound. The 50\% inhibitory concentration $\left(\mathrm{IC}_{50}\right)$, the concentration needed to cause toxic effects in $50 \%$ of intact cells, was calculable from graphic plots of the dose response curve for every concentration using Graph pad Prism software system (San Diego, CA. USA) [17] [18].

\section{Result and Discussion}

\subsection{Synthesis and Characterization}

The Schiff base ligand was prepared by condensation of mixture $(0.001 \mathrm{~mol})$ of 2-(4-isobutylphenyl)propane hydrazide and the 2,3,4-trihydroxybenzaldehyde in $(30 \mathrm{ml})$ methanol. The mixture was refluxing for $24 \mathrm{~h}$, The precipitated was filtered, crystallized by methanol, then dried in air for $24 \mathrm{~h}$. The Schiff base Platinum complex (L-Pt) was prepared by mixing $(0.001 \mathrm{~mol})$ of $\mathrm{K}_{2} \mathrm{PtCl}_{4}$ was dissolved in $10 \mathrm{ml}$ of methanol with some amount of deionized water and $(0.001$ mol) of Schiff base L in $20 \mathrm{ml}$ of methanol. The mixture was refluxing for $24 \mathrm{~h}$, The precipitated complex was filtered, washed twice with methanol, then dried in air for $24 \mathrm{~h}$. Table 1 summarized the physical properties (melting point, color, percentage yield, and elements analysis) of the ligand and its Pt complex. The proposed structure of Schiff base and L-Pt Complex were shown in Scheme 1. 
Table 1. Physical properties of Schiff base and its complex.

\begin{tabular}{|c|c|c|c|c|c|c|c|c|}
\hline No. & Unit formula & F. wt. & Color & Yield & M.P. ${ }^{\circ} \mathrm{C}$ & \multicolumn{3}{|c|}{$\mathrm{CHN} \mathrm{cal/(f)}$} \\
\hline 1 & $\begin{array}{c}\mathrm{L} \\
\mathrm{C}_{20} \mathrm{H}_{24} \mathrm{~N}_{2} \mathrm{O}_{4}\end{array}$ & 356 & Yellow & $80 \%$ & $\begin{array}{c}209- \\
210\end{array}$ & $\begin{array}{c}\text { C } \\
67.40 / 66.80\end{array}$ & $\begin{array}{c}\mathrm{H} \\
6.79 / 6.95\end{array}$ & $\begin{array}{c}\mathrm{N} \\
7.86 / 7.48\end{array}$ \\
\hline 2 & $\begin{array}{c}\mathrm{L}-\mathrm{Pt} \\
\mathrm{C}_{20} \mathrm{H}_{23} \mathrm{~N}_{2} \mathrm{O}_{4} \mathrm{PtCl}\end{array}$ & 585.94 & Black & $60 \%$ & $<300$ & $41 / 41.6$ & $3.93 / 3.43$ & $4.78 / 3.38$ \\
\hline
\end{tabular}

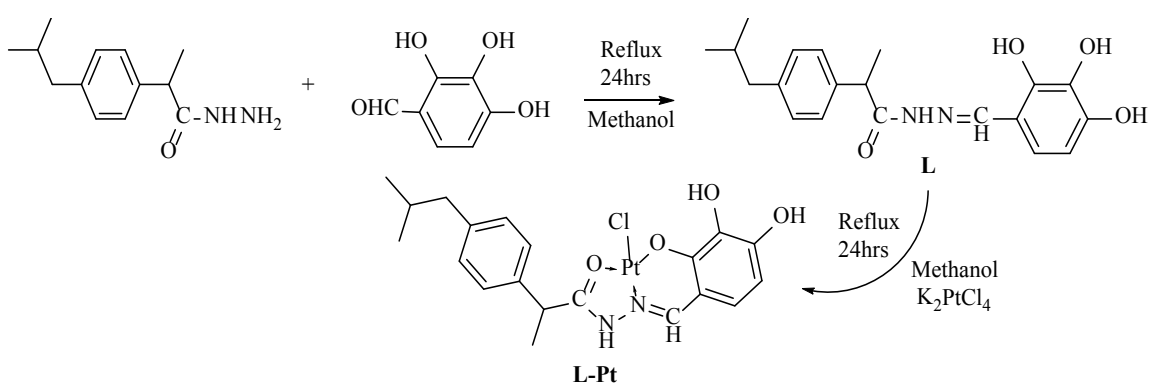

Scheme 1. The proposed structure of Schiff base L and its Pt complex L-Pt.

\subsection{IR Spectra}

The main IR Spectra of ligand and its complex are summarized in Table 2, The absence of the aldehydic carbonyl stretch in the ligand and the appearance of the characteristic azomethine $v \mathrm{C}=\mathrm{N}$ at $1633 \mathrm{~cm}^{-1}$ confirmed formation of the Schiff base. Comparison of infrared spectral data of Pt-complex and its corresponding ligand confirmed complexation as signification shifts in $v \mathrm{C}=\mathrm{N}$ was observed the strong band at $1633 \mathrm{~cm}^{-1}$ assigned to $v \mathrm{C}=\mathrm{N}$ in the free ligand shifted to higher wave number in Pt-complex at $1652 \mathrm{~cm}^{-1}$, indicating participation of azomethine nitrogen coordination. More ever, the single band at $3447 \mathrm{~cm}^{-1}$ due to the $v \mathrm{OH}$ vibration was shifted upon complexation, which confirmed the involvement of the $\mathrm{OH}$ hydroxyl group in coordination to metal ions [19] [20].

\subsection{NMR Spectra}

The main ${ }^{1} \mathrm{HNMR}$ spectrum of the $\mathrm{L}$, showed the azomethine proton at $\delta 8.6$ ppm $(\mathrm{s}, 1 \mathrm{H})$, while the multiples at $\delta(6.2-7.3) \mathrm{ppm}(\mathrm{m}, 6 \mathrm{H})$ were ascribed to aromatic protons, the $\mathrm{OH}$ were observed at $\delta 8.8 \mathrm{ppm}(\mathrm{s}, 1 \mathrm{H}), 9.7 \mathrm{ppm}(\mathrm{s}, 1 \mathrm{H})$ and $11.3 \mathrm{ppm}(\mathrm{s}, 1 \mathrm{H})$.

For the ${ }^{1}$ HNMR spectrum of the Pt (II) complex an electron density shift was observed from ligand to metal signal of azomethine proton appeared at $\delta 7.5$ ppm $(\mathrm{s}, 1 \mathrm{H})$ as compared to $8.6 \mathrm{ppm}$ in the ligand confirming coordination through the nitrogen of azomethine.

The ${ }^{13} \mathrm{C}$ NMR spectrum of the Schiff base had characteristic signals at $\delta 149$ ppm of the azomethine carbon, $\mathrm{C}=\mathrm{N}$ spectra were further characterized by absence of the aldehydic signal at $\delta 190 \mathrm{ppm}$ from the corresponding aromatic aldehyde (Figure 1). 
Table 2. Main IR absorption bands of Schiff base and its complex.

\begin{tabular}{ccccc}
\hline Compound & C=O amide & CH aliphatic & OH & HC $=\mathrm{N}_{\text {i } \min }$ \\
\cline { 2 - 5 } L & 1688 & 2953,2855 & 3478,3447 & 1633 \\
L-Pt & 1710 & 2951,2851 & 3432 & 1652 \\
\hline
\end{tabular}

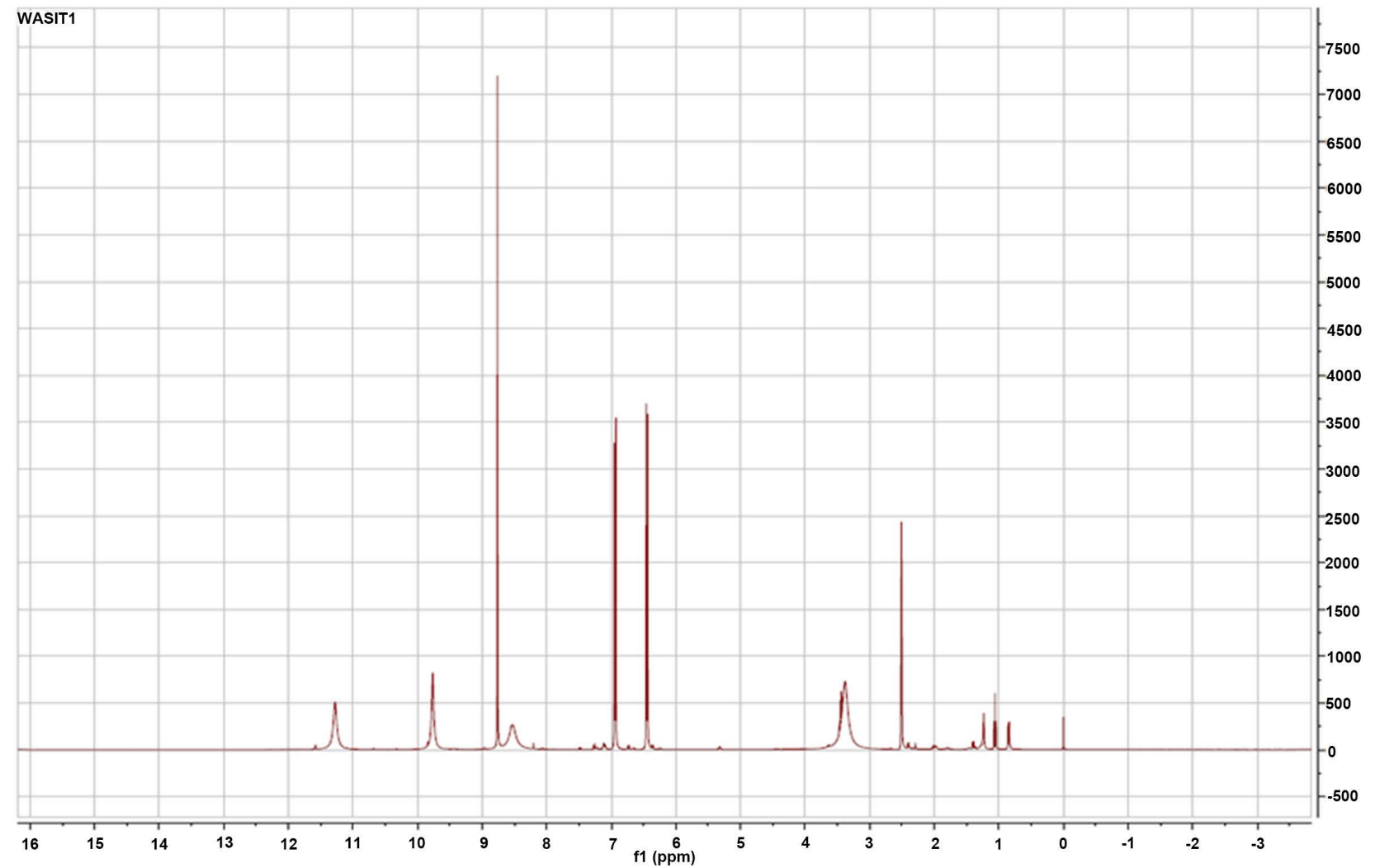

Figure 1. ${ }^{1} \mathrm{HNMR}$ spectrum of the ligand L.

\subsection{Electronic Spectra}

Electronic spectra were recorded in DMSO. The UV-Vis peaks confined to $\pi-\pi^{\star}$ and $n-\pi^{*}$ transitions of benzene and phenolic groups in the ligand. In the Schiff base, the band at $446 \mathrm{~nm}$ was attributed to the $\pi-\pi{ }^{*}$ of the azomethine. Bands between 371 and $231 \mathrm{~nm}$ are associated with phenyl and amide $\pi-\pi^{*}$ transitions. In the spectra of the complexes, the $\pi-\pi^{*}$ of the azomethine shifted to a shorter wavelength observed at $434 \mathrm{~nm}$, indicating that the hydrazone nitrogen was involved in coordination. The electronic spectra of the Pt (II) complexes had bands in the range of $381-227 \mathrm{~nm}$ shifted toward shorter and longer wavelength due to the $n-\pi^{*}$ and $\pi-\pi^{*}$ transitions of phenyl, lactam, and azomethine. In the spectra of the complex, the less intense and broad bands in the range of 580 660 and $757 \mathrm{~nm}$ resulted from the overlap of the energy $\pi \rightarrow \pi^{*}$ transitions, mainly localized within the azomethine group, lactam and the LMCT transitions from the lone pairs of the phenolate oxygen and of the azomethane nitrogen donor to Pt (II) [21] [22] [23]. 
Table 3. $\mathrm{IC}_{50}$ values $(\mu \mathrm{g} / \mathrm{ml})$ for Schiff base and Pt (II) complex tested against Helacells and PC3 cells.

\begin{tabular}{ccc}
\hline \multirow{2}{*}{ Compound } & PC3 & Hela \\
\cline { 2 - 3 } & $\mathrm{IC}_{50} \pm \mathrm{SD}(\mu \mathrm{g} / \mathrm{ml})$ & $\mathrm{IC}_{50} \pm \mathrm{SD}(\mu \mathrm{g} / \mathrm{ml})$ \\
\hline $\mathrm{L}$ & $30.5 \pm 3.9$ & $104 \pm 7.8$ \\
$\mathrm{~L}-\mathrm{Pt}$ & $22.4 \pm 2.7$ & $32.5 \pm 3.6$ \\
Cispalatine (as control) & $6.6 \pm 0.31$ & $7.76 \pm 0.4$ \\
\hline
\end{tabular}

\subsection{Anticancer Activity}

The results of in vitro anticancer activity of the tested the ligand and its Ptcomplex were evaluated for cytotoxicity against PC3 cells and Hela cells of humans in comparison with Cis palatine as a positive control. The L-Pt complex showed a higher cytotoxic activity than free ligand towards Hela cells and PC3 cells. Table 3 represents the cytotoxic activity of the tested compounds.

\section{Conclusion}

The present work describes the synthesis and in vitro anticancer activity of Schiff base and its complex Pt (II). The L-Pt complex showed a higher cytotoxic activity than Schiff base free ligand towards Hela cells and PC3 cells.

\section{Conflicts of Interest}

The authors declare no conflicts of interest regarding the publication of this paper.

\section{References}

[1] Naik, A., Annigeri, D., Gangardharmath, S.M.U., Ravankar, V.K., Mahale, V.B. and Reddv, V.K. (2002) Anchoring Mercapto-Triazoles on Dicarbonyl Backbone to Assemble Novel Binucleating, Acyclic SNONS Compartmental Ligands. Indian Journal of Chemistry-Section A, 41, 2046.

[2] Sen, A.K., Singh, G., Singh, K., Handa, R.N., Dubey, R.N. and Squattirito, P. (1998) Synthesis and Characterization of Some Monofunctional Bidentate Schiff Bases Derived from Cinnamaldehyde Ands-Triazoles, and Their $\mathrm{Co}(\mathrm{II}), \mathrm{Ni}(\mathrm{II}), \mathrm{Cu}(\mathrm{II})$ and $\mathrm{Zn}(\mathrm{II})$ Complexes. Proceedings of the Indian Academy of Sciences, 110, 75.

[3] Sen, A.K., Singh, G., Singh, K., Handa, R.N. and Dubey, S.N. (1997) Synthesis and Characterization of Some Monofunctional Bidentate Schiff Bases Derived from Furfuraldehyde and Their Cobalt(II), Nickel(II) and Copper(II) Complexes. Indian Journal of Chemistry $A, 36,891$.

[4] El-Shekeil, A.G., Abdubakr, A.O., AlAghbari, S.A. and Nassar, M.Y. (2014) Anticancer 4: Anticancer and DNA Cleavage Studies of Some New Schiff Base Titanium (IV) Complexes. European Journal of Chemistry, 5, 410-414. https://doi.org/10.5155/eurjchem.5.3.410-414.996

[5] Chambhar, R.V., Khadse, B.G., Bobde, A.S. and Bahekar, H.R. (2003) Synthesis and Preliminary Evaluation of Some N-[5-(2-furanyl)-2-methyl-4-oxo-4H-thieno[2,3-d] pyrimidin-3-yl]-carboxamide and 3-substituted-5-(2-furanyl)-2-methyl-3H-thieno [2,3-d]pyrimidin-4-ones as Antimicrobial Agents. European Journal of Medicinal 
Chemistry, 38, 89-100.

[6] Rathelot, P., Azas N., Elkashef, H. and Delmas, F. (2002) 1,3-Diphenylpyrazoles: Synthesis and Antiparasitic Activities of Azomethine Derivatives. European Journal of Medicinal Chemistry, 37, 671-679. https://doi.org/10.1016/S0223-5234(02)01388-0

[7] Holla, B.S., Malini, K.V., Rao, B.S., Sarojini, B.K. and Kumari, N.S. (2003) Synthesis of Some New 2,4-Disubstituted Thiazoles as Possible Antibacterial and Anti-Inflammatory Agents. European Journal of Medicinal Chemistry, 38, 313-318.

[8] Holla, B.S., Veerendra, B., Shiramanda, M.K. and Poojary, B. (2003) Synthesis Characterization and Anticancer Activity Studies on Some Mannich Bases Derived from 1,2,4-Triazoles. European Journal of Medicine, 38, 759.

[9] Saleem, L.M.N. (1982) Trans-cis Isomerization of Schiff's Bases (N-Benzylideneanilines) on Addition of Lanthanide Shift Reagents. Organic Magnetic Resonance, 19, 176-180. https://doi.org/10.1002/mrc.1270190403

[10] Wang, M., Wang, L.F., Li, Y.Z., Li, Q.X., Xu, Z.D. and Qu, D.Q. (2002) Antitumour Activity of Transition Metal Complexes with the Thiosemicarbazone Derived from 3-Acetylumbelliferone. Transition Metal Chemistry, 26, 307-310. https://doi.org/10.1023/A:1007159301849

[11] Gulerman, N.N., Rollas, S., Erdeniz, H. and Kiraj, M. (2001) Antibacterial, Antifungal and Antimycobacterial Activities of Some Substituted Thiosemicarbazides and 2,5-Disubstituted-1,3,4-Thiadiazoles. Journal of Pharmaceutical Sciences, 26, 1.

[12] Tarasconi, P., Capacchi, S., Pelosi, G., Corina, M., Albertini, R., Bonati, A., Dall'Aglio, P.P., Lunghi, P. and Pinelli, S. (2000) Synthesis, Spectroscopic Characterization and Biological Properties of New Natural Aldehydes Thiosemicarbazones. Bioorganic \& Medicinal Chemistry, 8, 154-162. https://doi.org/10.1016/S0968-0896(99)00260-6

[13] Charo, J., Lindencrona, J.A., Carlson, L.M., Hinkula, J. and Kiessling, R. (2004) Protective Efficacy of a DNA Influenza Virus Vaccine Is Markedly Increased by the Coadministration of a Schiff Base-Forming Drug. Journal of Virology, 78, 1132111326. https://doi.org/10.1128/JVI.78.20.11321-11326.2004

[14] Mishra, V., Pandeya, S.N. and Anathan, S. (2000) Antitubercular Actnity of Thioseniicarbazones and Semicarbazones. Acta Pharmaceutica Turcica, 42, 139.

[15] West, D.X., Carison, C.S., Liberta, A.E., Albert, J.N. and Daniel, C.R. (1990) Transition Metal Ion Complexes of Thiosemicarbazones Derived from 2-Acetylpyridine. Part 8. The Chemical and Antifungal Properties of the Nickel (II) Complexes of 2-acetylpyridine ${ }^{4} \mathrm{~N}$-Diethyl- and ${ }^{4} \mathrm{~N}$-Dipropylthiosemicarbazones. Transition Metal Chemistry, 15, 341-344. https://doi.org/10.1007/BF01177458

[16] Yale, H.L., Losee, K., Martins, J., Holsing, M., Perry, F.M. and Berstein, J. (1953) Chemotherapy of Experimental Tuberculosis. VIII. The Synthesis of Acid Hydrazides, Their Derivatives and Related Compounds ${ }^{1,2}$. Journal of the American Chemical Society, 75, 1933-1942. https://doi.org/10.1021/ja01104a046

[17] Mosmann, T. (1983) Rapid Colorimetric Assay for Cellular Growth and Survival: Application to Proliferation and Cytotoxicity Assays. Journal of Immunological Methods, 65, 55-63. https://doi.org/10.1016/0022-1759(83)90303-4

[18] Gomha, S.M., Riyadh, S.M., Mahmmoud, E.A. and Elaasser, M.M. (2015) Synthesis and Anticancer Activities of Thiazoles, 1,3-Thiazines, and Thiazolidine Using Chitosan-Grafted-Poly(vinylpyridine) as Basic Catalyst. Heterocycles, 91, 1227-1243. https://doi.org/10.3987/COM-15-13210

[19] Abeer, O., El-Shekeil, A., Al-Aghbari, S., Alshabi, J. and Coord, J. (2012) Anticancer, DNA Cleavage, and Antimicrobial Activity Studies of Some New Schiff-Base Ti- 
tanium(IV) Complexes. Journal of Coordination Chemistry, 65, 2762-2770. https://doi.org/10.1080/00958972.2012.703780

[20] Silverstein, M., Bassler, G. and Morril, C. (1981) Spectrometric Identification of Organic Compounds. 4th Edition, John Wiley \& Sons, New York.

[21] Kandil, S.S., Katib, S.M.A. and Yarkandi, N.H.M. (2007) Nickel(II), Palladium(II) and Platinum(II) Complexes of N-allyl-N'-pyrimidin-2-ylthiourea. Transition Metal Chemistry, 32, 791-798. https://doi.org/10.1007/s11243-006-0253-4

[22] El-Shekeil, A.G. and Al-Shuja'a O.M. (2007) Synthesis, Spectral Characterization, Thermal Studies and DC Electrical Conductivity of Poly[di(2,5-dimercapto-1,3,4thiadiazole)-Platinum(IV)] Complex. Journal of Macromolecular Science, Part A, 44, 445-451. https://doi.org/10.1080/10601320601188414

[23] Ulcan, M.G., Nmez, M.S.O. and Berber, I. (2012) Synthesis, Characterization, and Antimicrobial Activity of a New Pyrimidine Schiff Base and Its $\mathrm{Cu}(\mathrm{II}), \mathrm{Ni}(\mathrm{II}), \mathrm{Co}(\mathrm{II})$, Pt(II), and Pd(II) Complexes. Turkish Journal of Chemistry, 36, 189. 